November 4th, 1833.

(Held at the Society's Rooms, No. 17, Old Bond Street.)

J. G. Children, Esq., President, in the Chair,

Who, after having spoken of the objects and origin of the Society, and of the rapid advance of the science of Entomology in this country, resigned the Chair for the remainder of the evening to the Rev. W. Kirby, Honorary President.

The By-laws of the Socicty were read and adopted.

Williain Spence, Esq., F.R.S., \&c., was elected an Honorary En. glish Member, and W. B. Spence, Esq., was appointed Foreign Se cretary to the Society.

\title{
Donations.
}

Illustrations of British Entomology. By the Author, J. F. Stephens, Esq.

Systematic Catalogue of British Insects. By the same.

Nomenclature of British Insects, First Edition. By the same.

Ditto, Second Edition. Part I. By the same.

Synopsis of Nepaul Coleoptera. By the Author, the Rev. F. W. Hope.

Linnæi Systema Naturæ. By the same.

Dillwyn's Catalogue of the Coleopterous Insects of Swansea. By the same.

Sphinx Vespiformis, an Essay. By the Author, Edward Newman, Esq., F.L.S., \&c.

Entomological Magazine, Vol. I. By the Publishers.

Six Boxes of Exotic Coleoptera and Lepidoptera, By J. G. Children, Esq.

Four Boxes of Coleoptera and Lepidoptera. By the Rev. F. W. Hope.

Several Boxes of Insects. By the Rev. C. S. Bird and Samuel Hanson, Esq.

Various Insects. By W. E. Shuckard, E. Newman, A. H. Davis, and F. Walker, Esqrs.

\section{MะMorrs, \&c.}

An extract of a Letter was read, containing an account of the Entomological Proceedings at the Meeting of the German naturalists at 
Breslau on the 18th and 19th of September 1833. A Section for Entomology was established, having l'rof'essor Zawadski for the President, and Professors Gravenhorst and Schummel for Secretaries. M. Fitzinger of Vienna announced a new work on the $\mathrm{Or}$ thoptera, by Professor Reichenbach, and the completion of the work upon European Lepidoptera by Treitschke. Dr. Hammerschmidt exhibited a new Austrian species of Gryltus, and read a notice upon Lophyrus piniperda; he also announced a work by the lioyal Agricultural Society of Vienna upon Noxious Insects, and communicated several Memoirs upon Tinea granella by Messrs. Kollar and himself, upon Bostrichus typographus and villosus by the Count de Beraldingen, upon Haltica by Dr. Wundram, and upon Noctua aquilina by M. Kollar. He also made some observations upon a new Dipterous insect, the Cecidonyia Tritici, which during the year had caused great ravages to the wheat in Hungary. Also upon the galls upon plants produced by insects, with an attempt at their classification, which he illustrated by figures of not less than 950 different species of galls, and the insects producing them. He also stated, that having reared the larve (which he exhibited) of Eucnemis defexicollis and $E$. pallida, these insects were only varieties of the same species, as is also the case with Engis humeralis and E. pallida. He also exhibited various specimens of Diaperis Boleti, which he had reared, and which, from their great difference in size, proved that this character was inapplicable to the distinction of species; likewise two Coleopterous monstrosities, namely, a Procrustes Coriaceus with a tubercle on each elytron, and a Carabus morbillosus with a forked appendage upon each elytron; as well as two new Coleoptera, Plilium sulcatum and Latridius ruficollis; a new species of Arachnida, Thomisus togatus; and some remarkable varieties of Salticus sanguinolentus, Eresus 4-guttatus, and Epeira cucurbitina. He also read various Memoirs upon the larvæ and imagines of Cionus Scrophularia, Esalus Scarabcoides, Nematus intercus, Pyrochroa coccinea, Nosodendron fasciculare, T'enebrio molitor, Achet a gryllotalpa, Staphylinus hirtus, Mylabris variabilis, Meloe proscarabceus, Pimpla impressor, and Irixagus fumalus; and exlibited the preparatory states of the following Coleopterous insects, viz., Scolytus Pruni, Coccinella impunctata, Saperda punctata, Trichodes apiarius, Malthinus biguttatus, Malaclius aneus, T'lephorus fuscus, Trogosita caraboides, Megagnathus mandibularis, Pyrochroa coccinca, ZEsalus Scarabceoides, Silpha subterranea, Eccoptogaster Scolytus, I'riplax nigripennis, Cerylon sulcicolle, Synchita humeralis, and Hololepta plana. Professor Zawadski exhibited various new Coleoptera from 
the Carpathian Mountains, belonging to the Carabidce and Curculionida. He also announced the return of an entomological expedition undertaken in the Balkan Mountains. Professor Schummel read a Memoir upon Tipula, and described two new Diptera, under the names of Hammerschmidtia vittata and Dryomyza Zamadskii: he also exhibited various Plates, representing species of Lygaus, Coreus and Syrphus. Prof:ssor Gravenhorst gave some account of the Proceedings of the Entomological Society of France: he mentioned the exclusion of a Lepidopterous hybrid produced from the union of Platypteryx falcula and curvatula, and read a letter from Dr. Berendt of Dantzig, upon insects found imbedded in amber. $M$. Rottermond communicated a mode of taking the impression of the wings of Lepidopterous insects. M. Schilling described a new mode of ciassifying the Lepidoptera from the wings. He also mentioned the discovery of a new and winged species of Cimex ( $C$. domestica). M. Boksch mentioned a hybrid union between Melolontha Hippocaslani and valgaris, of which he had been witness. Professor Mikan of Prague read the description of thirteen new species of Iulus from Brazil. M. Jaensch spoke of the species of the genera Melolontha and Bostrichus injurious to agriculture. M. Klopsch read a Memoir upon the state of Entomology in the time of Aristotle; and the return of Messrs. Ecklon and Bescke from an entomological voyage to Brazil was announced.

Mr. Spence, in allusion to Dr. Hammerschmidt's Memoir upon the Cecidomyia, stated that the insect described by that author was specifically distinct from the long previously described Cecidomyia Tritici of Kirby : the injury done by the former insect is occasioned by the larva eating the stem, thereby weakening the plant, whereas the latter feeds upon the flowers of the wheat, thereby preventing their fructification. The Hessian fly described by Mr. Say-(see Loudon's 'Magazine of Natural History,' No. 3, for a notice of Mr. Say's Memoir, by Mr. Kirby,) -is also distinct, although evidently congenerous; but the immense injury which it causes is said to arise from the pressure of the pupæ against the grain while in a tender state. Mr. Spence, however, considered that this fact had need of confirmation, and called the attention of the Meeting to the necessity of minute investigation into the oconomy of the various species of insects destructive to agricultural productions. 